\title{
TEACHING METHODOLOGIES FOR NEW PROFESSIONAL PROFILES IN THE TRANSLATION MARKET: WEB LOCATORS
}

\author{
Juncal Gutiérrez-Artacho, María-Dolores Olvera-Lobo \\ University of Granada (SPAIN)
}

\begin{abstract}
Constant changes in the economic environment, where globalisation and the development of the knowledge economy act as drivers, are systematically pushing companies towards the challenge of accessing external markets.
\end{abstract}

Web localization constitutes a new field of study and professional intervention. From the translation perspective, localization equates to the website being adjusted to the typological, discursive and genre conventions of the target culture, adapting that website to a different language and culture. This entails much more than simply translating the content of the pages. The content of a webpage is made up of text, images and other multimedia elements, all of which have to be translated and subjected to cultural adaptation. The user must never notice that the site was originally created in another language. In addition, commercial and business translation have certain particularities which must be studied and borne in mind so as to achieve the desired communication goals.

The translation process entails that a language professional will perform various roles, completing each stage on time and undertaking multiple tasks in order to meet the conditions for delivery of the translation in accordance with certain quality parameters (Olvera-Lobo et al., 2007a, 2007b, 2008a, 2008b, 2009, 2011, 2014, 2015; Robinson et al., 2011, 2013, 2016). For its part, localization involves different agents in the localization process although their number may vary from a sole person responsible of the entire process to a multiplicity of agents in large organisations: managers of businesses, localization managers, localization engineers, terminologists, locators, quality control operators and freelance translators, among others. The process also varies considerably depending on the nature of the project (marketing website, web-based application, e-commerce site, and so on), the technologies involved, the resources available and even the type of translation process employed.

This contribution presents the application of a new teaching methodology to the teaching/learning of localization in the undergraduate training of Translation and Interpreting, applying the didactic model PATT (Professional Approach to Translation Training), widely extended in the teaching of Translation, that has been adapted to the new characteristics of this new professional profile. In the context of localization we have revised and redesigned the model to integrate knowledge and skills required in localization.

The revision of PATT has involved modifications to enhance the quality of the learning experience of localization students and make the assessment process more transparent. These changes entailed more detailed scaffolding to incorporate a range of tasks enabling learners to further exercise higher order thinking skills.

In this contribution we present a new didactic model adapted to the localization learners and their application in the localization process.

Keywords: Localization, translation, translation training, new markets.

\section{INTRODUCTION}

Localization forms part of the group of interdependent process known by the acronym GILT: Globalization, Internationalization, Localization, Translation [1]. If we look at them individually it can be established that translation is a process by which the meaning of a written text in a source language is communicated through an equivalent text in the target language. Regarding localization, the most popular definition, put forward by the now disappeared Localization Industry Standard Association, maintains that this activity involves taking a product and making it linguistically and culturally appropriate for a locale, that is, the country and target language in which the product in question will be used and sold [2]. Although we speak about the localization of software, videogames and apps, amongst others, it is true that in the last few years we have witnessed the unprecedented growth of 
web localization, a communicative, technological, textual and cognitive process by which interactive digital texts (or websites) are modified for use by an international public which is not the use initially foreseen [3]. For its part, internationalization consists in identifying all local information that appears on a website, that is, that information that is dictated by the language and culture of the country where it was originally designed, for example, dates, numbers, currency, contact information, etc. These elements must be isolated and saved independently so they can be adapted to the specifications of any language. Lastly, globalization combines the processes of internationalization and localization. It consists of the design of websites that can be used in different countries with a minimum of changes. It is a concept that belongs more to the marketing than the technical department.

The success of websites as global communication platforms, the exchange of information or the selling of products and services has been pronounced in the development of localization processes, closing the gap between Internet users from different socio-cultural and linguistic contexts The economic importance of this phenomenon is increasing, and its significance is borne out by the growing body of research dedicated to localization, specialised conferences and the number of institutions offering training courses for professionals in this area.

\subsection{Approximation and review of competences in the Translating and Interpreting degree}

Adapting to Bologna has meant rewriting university curricula to meet the general guidelines established by the TUNING project and this study examines examples taken from the undergraduate programme in Translation and Interpreting at the University of Granada, Spain, which has drawn on a range of competences learners should acquire in the course of their studies [12-15]. Competences are classified in two broad groups-general (or transversal or generic) and specific-and subdivided into personal, systemic and instrumental, and academic/discipline-based and professional, respectively. In many programmes, specific competences reflect the traditional content-based programmes they replace, allowing teachers to reformulate the same knowledge-based contents in a different manner. Similarly, an overlap exists between the instrumental and professional competences and the practical components of earlier programmes. However, the broadening of scope represented by introducing competences constitutes the major challenge in implementing change. Personal, systemic and instrumental competences are wide-reaching and go beyond anything the former programmes contemplated, involving areas of our learners' individual development that were not previously given explicit consideration.

\subsection{Professional Approach to Translator Training (PATT)}

The dynamic nature of translator training, set as it is against a background of exponential growth in Information and Communication Technology, is a constant source of challenge to all concerned. Training translators involves a wide range of activities based on team work and the performance of project-based learning tasks. The "translation project" is essential to the terminology of translator training in the pursuit of a workplace model to simulate. However, student assessment has traditionally been product-oriented with the translated text being considered the only evidence of successful learning. The complex nature of the process that leads to the production of a final translation is assumed to be assessed via the translation itself. Our post-Bologna curriculum is constructed around a detailed inventory of general and specific competences and assessment should cover the full range of transversal competences including the instrumental, personal and systemic competences associated with, for example, the fulfilment of learning projects or team work. It is no longer sufficient to assess the product alone even though the challenge of assessing the process is much more demanding since our attention as assessors needs to focus on far less tangible factors. Essentially, assessing the product is a lesser challenge as we are dealing with a document that can be measured against predefined and agreed descriptors or protocols; to assess a product gives rise to objective comparison that can be replicated. To assess a process involves a lower level of certainty as to the objectivity of our judgement and of our ability to replicate the object, hence the value of the criteria used will depend on how solid, shared and verifiable they are. The nature of the professional development of the translator and the essential content of the core curriculum encompass theoretical and practical knowledge that reflect the core of the discipline and, at the same time, the principle roles that each translator, individually or as a member of a team, needs to perform in daily professional life. To this end, and in line with a social-constructivist approach, our project-based learning translation project is tightly structured and embraces a wide range of competences. Clearly, this model represents a basic structure that can easily be adapted to different course modules. 


\section{METHODOLOGY}

The essential characteristics of cooperative learning are positive interdependence, the group task, individual responsibility, and the use of interpersonal and group interaction techniques [16-19]. The work groups are teams of four or five learners.

The translation project is divided into four iterative stages: (a) documentation, (b) terminology, (c) translation, and (d) revision and editing; project management itself constitutes a fifth component (Figure 1). The choice of five as the target number of members for each team is founded on the fact that it coincides with the roles-documentalist, terminologist, translator, reviser, and project leader. Learners are made aware of the motives behind this and advised to organize themselves within each team as they see best, with the proviso that over the semester they should all take each of the different roles an equal number of times. Teamwork and the competences involved are the focus of one presentation and one reflective writing activity during the semester as well as the objective of the collaborative teamwork peer-assessment.

Initially, the PATT model was designed to coordinate the learning taking place in a series of core and elective course modules that ran across three of the four years of the undergraduate degree programme [20-47]. The modules in question were a 2 nd year core course in "Applied Documentation for Translation Studies"; a 3rd year core course in "Terminology"; and 3th year electives in "Scientific and Technical Translation (B-A) English into Spanish". The chronological order of the discrete elements that constituted each translation project (Figure 1) involved coordination between lecturers and students in at least four of these modules.

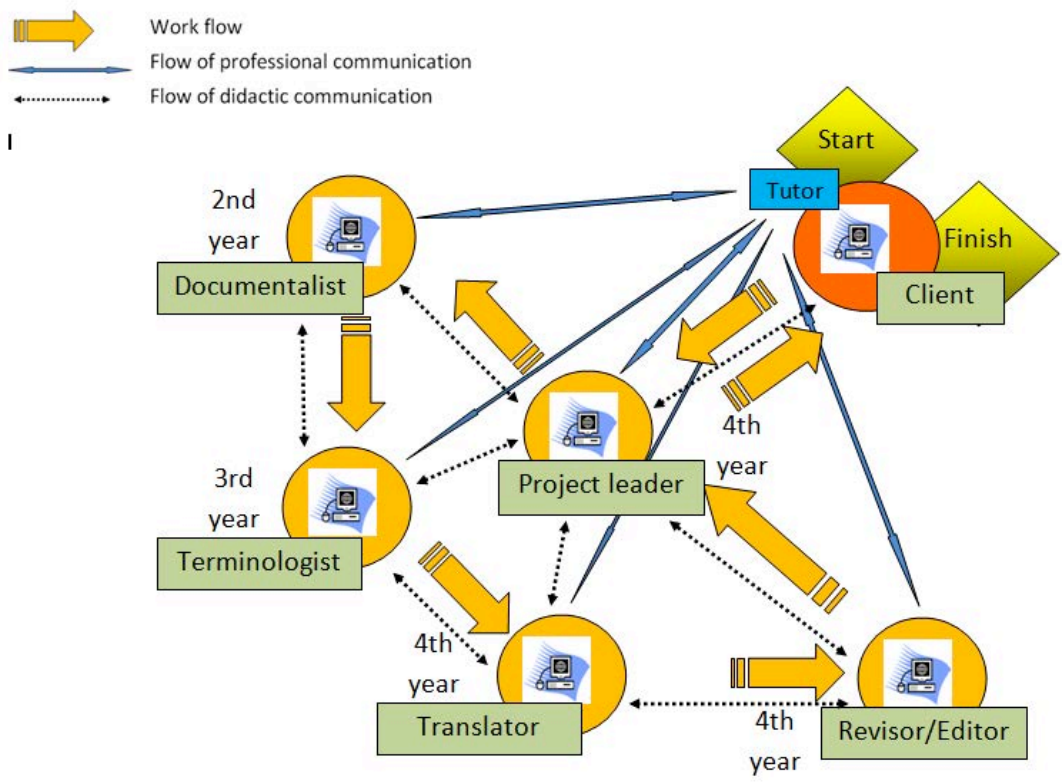

Figure 1. The original PATT design (Olvera-Lobo et al. 2007).

However, in the context of a single module these were overcome by refining the model to integrate knowledge and skills acquired on core courses within a single elective. The revision of PATT (figure 2) involved modifications to enhance the quality of the learning experience and make the assessment process more transparent. Informed by the Bologna process, these changes entailed more detailed scaffolding to incorporate a range of tasks enabling learners to further exercise higher order thinking skills. Initially the translation project began with a translation brief and ended with a target text; the revised model added self- and peer-assessment tasks requiring students to learn and consolidate their ability to apply translation quality criteria and, thus, develop their use of the higher order thinking skill of evaluating. The range of competences explicitly taught, practised and assessed incorporated visual presentation design and oral presentation skills along with an opportunity for individual reflection. Most recently, individual self- and peer-assessment of collaborative team processes has been introduced [21]. 


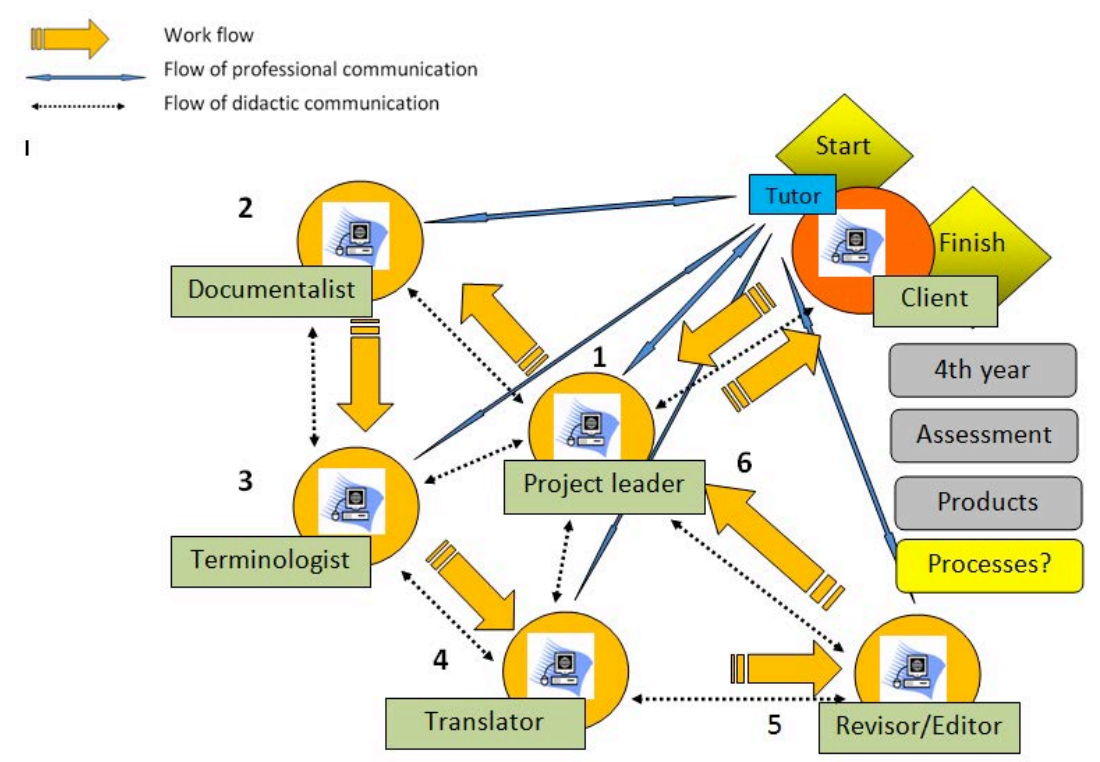

Figure 2. The extended PATT design.

The extended PATT was applied in the module 'Specialised Translation English to Spanish', specifically in the part focussing on technical/scientific translation. It is a compulsory assignment in the third year of the Translation and Interpreting degree at the University of Granada. Students were organised in six groups with the above-mentioned characteristics for them to carry out the continuous assessment tasks. There were 10 tasks in total, with each student having to undertake and present 5 translations in a group and a further 5 individually. To facilitate the students' work, on day one a lecture was given on the extended PATT characteristics, and the students were provided with a document entitled 'Work dynamic' which explained the methodology in the classroom.

In order to carry out our project, we identified and analysed the game mechanics which are best adapted to the subjects and competences connected with the Translation and Interpreting degree. Game mechanics are a series of rules concerning the creation of games which can be enjoyed, and which generate bonding and commitment among students as they provide challenges and a path to follow, whether in a game or in some type of application. While there are many game mechanics, we will focus on the most prominent or habitually applied in the gamification of activities that are not particularly recreational. A report was prepared which identified and analysed the game mechanics (challenges, opportunities, competition, co-operation, feedback, transactions, turns, points and levels, among others) that are best adapted to the subjects and competences related to the Translation and Interpreting degree.

The 10 translations involved medical and technical texts of different characteristics and specialisations. The students were not given marks for their translations but rather the methodology of videogames was followed to reward the players in order to monitor their progress. Each group had its insignia and the students were rewarded with points and successes. Although this methodology has been employed in education for many years, using the likes of prizes and certificates of merit, gamification is more than that. When using game dynamics, users are guided towards those objectives. It does not concern winners and losers. Gamification leads to a smaller number of 'losers' because users follow the path in a personalised way. Rather than all the users having to advance at the same rhythm, with gamification models the user goes at his or her own rhythm when reaching his or her own milestones and so receiving emotional rewards.

In order to organise the dynamic in class and carry out these assessments, on day one they were told given a series of materials, listed below, which were explained to them:

- Planning of the subject

- Timetable of activities

- Work dynamic

- Classification of translation errors 


\section{RESULTS}

The extended version of PATT has been better adapted to the characteristics of the classroom and has allowed for the implementation of gamification models in the marking process. The students who have undergone the continuous assessment (more than $90 \%$ of the total) have carried out various assessment processes of their translations and of their classmates by way of self-assessment, peer assessment and group assessment. Each correction of a task has led to proposals for different assessment models in the teaching guide for the assignment and the White Book for the Translation and Interpreting degree. In addition, each group of students has presented a translation to the entire class, and the other students have had to assess and evaluate certain parameters pursuant to a previously established checklist. All those assessments were assigned with successes and rewards from which the final marks of the students were then extracted.

The first type of assessment applied has been peer assessment. Each student had a role: client or translator. The student acting as the client was given a document with ticks and terminology that allowed for a better understanding of the job. The 'client' students had to assess the work of their classmates with regard to the successes achieved and the mistakes made, giving a weight to each of them in accordance with the initial class material. The objective was not only to detect the mistakes made by the other student, but also that by working together they could obtain an overall view of the translation process.

Once the students had learned about peer assessment, the subsequent tasks were subject to a twofold assessment: peer translation and subsequent assessment. Thus, not only did the students have an idea of the general mistakes and successes, they also had a critical, assessed view of their own work. Finally, all the members of each work group jointly assessed the translations of the other groups, assigning an evaluation of the most significant successes and failures and marking them in accordance with the general parameters.

All the successes achieved were noted by the appropriate lecturer and the final mark for the continuous assessment was obtained from them.

All the students gave a positive final assessment to this learning model, as did the teaching staff who noted the acquisition of certain skills and competences not assessed in the teaching guide for the assignment.

\section{CONCLUSIONS}

In the present article, we have attempted to contextualize the innovative process of evolution and adaptation that translator training has undergone at the University of Granada (Spain) in order to adopt a learner- and competence-centred approach that fully aligns with the post-Bologna model of tertiary education and include the gamification in the courses. The PATT model that we describe has grown increasingly sophisticated, and continuous testing and refinement of transparent assessment tools has enabled us to create a learning/teaching environment that draws on the most productive aspects social constructivism offers learners in the 2010s. Our innovations have reflected the pace of change that Information and Communication Technology has brought about in the current century, when new developments render course content input out of date between one academic year and the next, thus constantly obliging digital immigrant university teachers to retrain in order to catch up with their digital native learners.

We have described a blended e-learning course environment closely attuned to the reality of the digital native generation through rigorous integration of gamification through the evaluation and assessment. While our work clearly has limitations, due to the need for larger-scale empirical validation and its focus solely on translator training, we consider it shows great potential as a means of ensuring major enhancements in the quality of the learning experience for digital native students and that the essential approach is applicable throughout tertiary education far beyond the confines of a single discipline. 


\section{ACKNOWLEDGEMENTS}

The authors are grateful to the Spanish "Ministry of Science and Innovation" for supporting this study, in the framework of the research Project CSO2015-64532-R, partially funded by the FEDER program of the European Union.

\section{REFERENCES}

[1] Cadieux, P.; Esselink, B.: GILT: Globalization, Internationalization, Localization, Translation. Globalization Insider, 11 (1.5): 1-5 (2004).

[2] LISA. Localization Industry Primer. Geneva: Localization Industry Standards Association (2003).

[3] Jiménez-Crespo, M. A.: Translation and Web Localization. New York: Routledge (2013).

[4] Cortizo Pérez, José Carlos, et al. (2011). Gamificación y Docencia: Lo que la Universidad tiene que aprender de los Videojuegos. VIII Jornadas Internacionales de Innovación Universitaria.

[5] Anderson J.; Rainie, L. (2012). "The Future of Gamification", http://www.pewinternet.org/2012/05/18/the-future-of-gamification/, Pew Research Internet Project, 18th/May/2012

[6] Freitas, S., Neumann, T. (2009). The use of exploratory learning for supporting immersive learning in virtual environments. Computers \& Education, vol. 52, núm. 2, pp. 343-352, february de 2009 .

[7] Gallego, C.J. Villagrá, R. Satorre, P. Compañ, R. Molina, F. Llorens (2014). Panorámica: serious games, gamification y mucho más. ReVisión, Vol 7, No 2.

[8] Brodsky, M. W. (2003). Four Blended Learning Blunders and How to Avoid Them. Learning Circuits, November 2003.

[9] Coaten, N. (2003). Blended e-learning. Educaweb, 69. 6 de octubre de 2003.

[10] Reay, J. (2001). Blended Learning - A fusion for the future. Knowledge Management Review.

[11] Bartolomé, A. (2002). Universidades en la Red. ¿Universidad presencial o virtual?. Crítica, LII (num. 896), pp. 34-38.

[12] Pascual, $M^{a}$ (2003). El Blended learning reduce el ahorro de la formación.

[13] Salinas, S. J. (1999). ¿Qué se entiende por una institución de educación superior flexible?. Comunicación presentada en Congreso Edutec 99. NNTT en la formación flexible y a distancia, 14 a 17 de septiembre 1999, Sevilla.

[14] Pagani, R. (2002). El crédito europeo y el sistema educativo español. Available at: http://www2.ulpgc.es/descargadirecta.php?codigo_archivo=4857 (last accessed 30 December 2014).

[15] Cózar Sievert, R.D. (2003). El cambio de mentalidad para la convergencia europea (Unpublished presentation): University of Sevilla, Spain.

[16] Cózar Sievert, R.D. (2003). Tuning Educational Structures in Europe (Unpublished presentation): University of Sevilla, Spain.

[17] González, J., Wagenaar, R. (2003). Quality and European Programme Design in Higher Education. Available at: http://www.unizar.es/eees/tesie/TUNING_II_2003/Article.pdf

[18] Alorda, B., Suenaga, K. and Pons, P. (2011). Design and Evaluation of a Microprocessor Course Combining Three Cooperative Methods: SDLA, PjBL and CnBL. Computers \& Education 57 (3), pp. 1876-1884.

[19] Chen, H. (2006). Projects-To-Think-With and Projects-To-Talk-With: How Adult Learners Experience Project-Based Learning in an Online Course. Unpublished doctoral dissertation, Kansas State University, Manhattan, Kansas.

[20] Kiraly, D.C. (2005). Project-based Learning: A Case for Situated Translation. Meta 50 (4), pp. 1098-1111. 
[21] Kurubacak, G. (2007). Building Knowledge Networks through Project-Based Online Learning: A Study of Developing Critical Thinking Skills Via Reusable Learning Objects. Computers in Human Behavior 23 (6), pp. 2668-2695.

[22] Castro-Prieto, R.M.; Olvera Lobo, M.D. 2007. Panorama intelectual de la terminología a través del análisis de redes sociales, La traduction et les études de réseaux / Translation and Network Studies, Meta, Journal des traducteurs, 52 (4), pp. 816-838.

[23] Robinson, B. J., Olvera-Lobo, M. D., \& Gutiérrez-Artacho, J. (2016). After Bologna: Learnerand Competence-Centred Translator Training for "Digital Natives". In Martín de León, Celia; González-Ruiz, Víctor (eds.). 2016. From the Lab to the Classroom and Back Again: Perspectives on Translation and Interpreting Training. Frankfurt am Main: Peter Lang (New Trends in Translation Studies Series).

[24] Olvera-Lobo, M.D.; Gutiérrez-Artacho, J.; Hunt Gómez, C.I.; (2015). FORmación Transversal en TRAducción desde una perspectiva profesional: FORTTRAPI. XII Foro Internacional sobre la evaluación de la calidad de la investigación y de la educación superior (FECIES).

[25] Robinson, B.J.; Olvera-Lobo, M.D.; Gutiérrez-Artacho, J. (2015). Trainee translators' perceptions of cooperative teamwork. In: Corpas Pastor, G. et al. (eds) AIETI7 (Asociación Iberica de Estudios de Traducción e Interpretación): Nuevos horizontes en los estudios de traducción e interpretación. Tradulex: Geneva, pp. 375-393.

[26] Robinson, B.J.; Olvera-Lobo, M.D.; Escabias-Machuca, M.; Gutiérrez-Artacho, J. (2015). Using rubrics to scaffold learning. How the integration of criterion-referenced descriptors enhances student-centred formative assessment. IATIS $5^{\circ}$ International Conference, Belo Horizonte, Brasil, 7-10 Julio 2015.

[27] Olvera-Lobo, M.D.; Gutiérrez-Artacho, J. (2014). Web 2.0 Technologies in the translator training: Aulaint. EDULEARN14, 6th International Conference on education and new learning technologies. Barcelona, 8 de Julio de 2014, pp. 1562-1569. ISBN 978-84-617-0557-3.

[28] Olvera-Lobo, M.D.; Gutiérrez-Artacho, J. (2014). Herramientas de software libre en la docencia de la traducción (PID 12-139). Innovacion docente y buenas prácticas en la Universidad de Granada, pp. 710-722. Granada: Editorial Universidad de Granada. ISBN 978-84-338-5416-2.

[29] Olvera-Lobo, M.D.; Gutiérrez-Artacho, J. (2014). Academic use of custom social networks in translation training. Perspectives: Studies in Translatology, 22 (2): 282-289.

[30] Gutiérrez-Artacho, J.; Olvera-Lobo, M.D. Los procesos de enseñanza-aprendizaje de la traducción especializada desde la perspectiva profesional. Jornadas de Traducción hispanorusas. Moscú (Rusia), 18 y 19 Septiembre 2013.

[31] Olvera-Lobo, M.D.; Gutiérrez-Artacho, J. (2013). El aprendizaje de la traducción desde la perspectiva profesional: balance de una década. X Foro Internacional sobre la Evaluación de la Calidad de la Investigación y de la Educación Superior (FECIES). Granada, 27 de junio de 2013. ISBN 978-84-697-0237-6.

[32] Olvera-Lobo, M.D.; Gutiérrez-Artacho, J.; Robinson, B.J. (2013). Acciones formativas Web 2.0: el grado en traducción e interpretación como banco de pruebas. VI Congreso Internacional de la Asociación Ibérica de Estudios de Traducción e Interpretación (AIETI6). Las Palmas de Gran Canaria, 28 de enero de 2013.

[33] Robinson, B.J.; Olvera-Lobo, M.D.; Gutiérrez-Artacho, J.; (2013). Retorno al modelo profesional para la formación de traductores. VI Congreso Internacional de la Asociación Ibérica de estudios de traducción e interpretación (AIETI6). Las Palmas de Gran Canaria, 28 de enero de 2013.

[34] Robinson, B.; Olvera-Lobo, M.D. 2011. Facebook, Twitter or Tuenti? A first look at the academic use of web 2.0 social networks in translator training. En: Maruenda-Bataller, S.; Clavel-Arroitia, B. (eds.) Multiple voices in academic and professional discourse: current issues in specialised language research, teaching and new technologies. Newcastle: Cambridge Scholar, Chapter 34, 367-379.

[35] Olvera-Lobo, M.D.; Gutiérrez-Artacho, J. (2011). Initiatives and evaluation of teaching-learning process in translation training. En: Garant, M. (ed.) Current trends in translation teaching and learning. Helsinki: University. pp.79-95 . 
[36] Olvera-Lobo, M.D.; Quero-Gervilla, E.; Robinson, B.; Senso-Ruiz, J.A.; Castro-Prieto, M.R.; Muñoz-Martín, R.; Muñoz-Raya, E.; Murillo-Melero, M. (2010). Presentation of a distance training model for introduction into the practice of teaching translation according to the requirements of the Bologna declaration. Vestnik MGU. Seria $n^{\circ} 26$. Pedagogical Sciences: 605, 196-208. ISSN: 1993-4750.

[37] Olvera-Lobo, M.D.; Robinson, B.; Senso, J.A.; Muñoz-Martín, R.; Muñoz-Raya, E.; MurilloMelero, M.; Quero-Gervilla, E.; Castro-Prieto, M.R.; Conde-Ruano, T. (2009). Teleworking and collaborative work environments in translation training. Babel: international journal of translation, 55 (2): 165-180

[38] Olvera-Lobo, M.D.; Quero-Gervilla, E.; Robinson, B.; Senso-Ruiz, J.A.; Castro-Prieto, M.R.; Muñoz-Martín, R.; Muñoz-Raya, E.; Murillo-Melero, M. (2009). Predstavlenie modeli distantsionnoj raboty dlja vnedrenia $\mathrm{v}$ praktiku prepodavania perevoda $\mathrm{v}$ sootvetsvii $\mathrm{S}$ trebovaniami Bolonskoj deklaratsii // Presentación de un modelos para la enseñanza a distancia de la traducción de acuerdo con las exigencias de la declaración de Bolonia. Vestnik MGU. Seria $\mathrm{n}^{\circ}$ 22. Teoria Perevoda: 1, 62-75. ISSN: 1697-4239.

[39] Olvera-Lobo, M.D.; Castro-Prieto, R.M.; Quero-Gervilla, E.; Muñoz-Martín, R.; Muñoz-Raya, E.; Murillo-Melero, Miguel; Robinson, B.; Senso-Ruiz, J.A. Collaborative Work Learning in Higher Education. In: Putnik, G. D. and Cunha, M.M. (ed.) Encyclopedia of Networked and Virtual Organizations. Hershey: Idea Group, 2008. ISBN: 9781599048857. Pp. 261-268.

[40] Olvera-Lobo, M.D.; Robinson, B.J.; Senso, J.A.; Muñoz-Martín, R.; Muñoz-Raya, E.; MurilloMelero, M.; Quero-Gervilla, E.; Castro-Prieto, M.R.; Conde-Ruano, T. (2007). Student satisfaction and perceived improvement with a Web-based collaborative work platform". Perspectives: Studies in Translatology, 15 (2), pp. 106-122.

[41] Olvera-Lobo, M.D.; Quero-Gervilla, E.; Robinson, B; Senso-Ruiz, J.A.; Castro-Prieto, M.R.; Muñoz-Martín, R.; Muñoz-Raya, E.; Murillo-Melero, M. (2007). A professional approach to translator training (PATT). Meta, Journal des traducteurs, 52 (4), pp. 517-528.

[42] Olvera-Lobo, M.D.; Quero-Gervilla, E.; Robinson, B; Senso-Ruiz, J.A.; Castro-Prieto, M.R.; Muñoz-Martín, R.; Muñoz-Raya, E.; Murillo-Melero, M. (2007). "Nobye Informatisionnye i Kommunicatsionnye texnologii v kurse prepodavania perevoda = Las nuevas tecnologías de la información y la comunicación aplicadas a la enseñanza de la traducción". En: Guzmán Tirado, R. et al. (eds). Congreso Internacional "La lengua y la literatura rusas en el espacio educativo internacional: estado actual y perspectivas" Mocba: Mirs, 2007. Tomo 2. pp. 1259-1264 ISBN 978-5-91395-002-4.

[43] Senso, J.A.; Olvera-Lobo, M.D.; Vargas-Quesada, B.M.; Castro-Prieto, M.R.; Muñoz-Raya, E.; Muñoz-Martín, R.; Murillo-Melero, M. y Robinson, B. (2006). Evaluación del uso de una herramienta de trabajo colaborativo en la docencia de la Traducción: análisis de ficheros log. In: Conferência IADIS Ibero-Americana WWW/Internet 2006. p. 57-66. ISBN 972-8924-20-8.

[44] Olvera Lobo, M.D.; Castro Prieto, M.R Robinson, B.; Quero, E.; Muñoz Martín, R.; Muñoz Raya, E.; Murillo, M.; Senso, J.A.; Vargas; Domínguez-López, C. (2005). Translator Training and Modern Market Demands. Perspectives: Studies in Translatology. 13 (20): 132-142.

[45] Olvera Lobo, M.D.; Castro, M.R.; Quero, E.; Muñoz Raya, E.; Muñoz Martín, R.; Murillo, M.; Robinson, B.; Senso, J.A. y Vargas, B. (2005). Aplicación de un modelo profesional para la didáctica de la traducción. Eslavística Complutense. 4: 249-255. ISSN: 1578-1763.

[46] Quero, E.; Olvera Lobo, M.D.; Castro Prieto, M.R.; Muñoz Raya, E.; Muñoz Martín, R.; Murillo, M.; Robinson, B.; Senso, J.A.; Vargas, B. (2004). "Aplicación de un modelo profesional para la enseñanza de la traducción (Aulaint) dentro de la asignatura traducción científico-técnica C-A Ruso". IX Seminario Hispano-Ruso de Traducción e Interpretación. Universidad Estatal Lingüística de Moscú del 8-15 de mayo 2004.

[47] Olvera-Lobo, M.D.; Castro-Prieto, R.M.; Muñoz Martín, R.; Robinson, B.; Villena, I. (2003). Nuevas tecnologías y didáctica de la traducción. Innovación docente vía Internet. Revista Universitaria ICE, 21: 97-108. ISSN: 1131-5245.

[48] Olvera-Lobo, M.D.; Castro-Prieto, R.M.; Muñoz Martín, R.; Robinson, B.; Villena, I. (2003). Aula virtual de traducción: Aula. Int. Proyecto de innovación docente". I Congreso Internacional de la 
Asociación Ibérica de Estudios de Traducción e Interpretación (AIETI). Granada, del 12 al 14 de febrero de 2003, p. 471-489. ISBN: 84-933360-0-9.

[49] Quero, E.; Olvera-Lobo, M.D.; Castro-Prieto, R.M.; Muñoz Martín, R.; Muñoz Raya, E.; Robinson, B.; Murillo, M.; Senso, J.A.; Vargas, B. (2003). Aplicación de un modelo didáctico de enseñanza de la traducción. Congreso-Seminario Internacional Complutense "Las lenguas y culturas de los países de la ampliación de la Unión europea: nuevas perspectivas de cooperación internacional". Universidad Complutense de Madrid del 19-21 de noviembre de 2003. 